\title{
ws003 Affective Neuroscience for Psychologists 9 一社会的・文化的な感情神経科学一
}

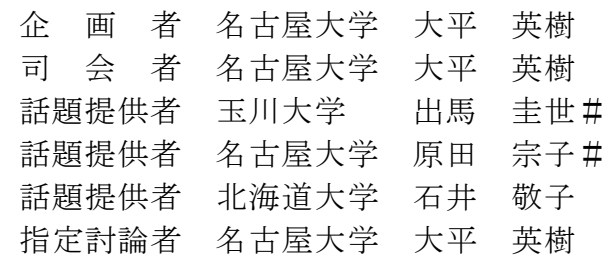

\section{概 要}

本学会大会において、過去 8 回にわたり、近年の感情に関する神経科学的研究の知見を紹介し、そうした 知見が心理学に対してどのようなインパクトを与えるのかを議論するためのワークショップを開催してきた。 本年は、最近発展が著しい、社会的・文化的要因を考慮した感情神経科学を取り上げる。ヒトの感情は進化 の中で形成され、そのメカニズムは他の動物とも強い連続性を持つ。しかしヒトは社会的環境を作り上げて きたために、我々の感情システムもそこに適応するように発展してきたと考えられる。本ワークショップで は、こうした問題にどのように神経科学的なアプローチが可能であるかを検討する。具体的には、他者から の良い評判という社会的報酬が金銭報酬と同様に「脳内の通貨」として働く神経基盤、内側前頭前野によっ て担われる自己に関わる処理の文化差に関する神経画像研究、原因帰属・推論・注意配分などの社会的認知 を支える神経基盤の文化拘束性、などの問題を取り上げる。 